\title{
Financiamento, Crescimento Econômico e Funcionalidade do Sistema Financeiro: Uma Abordagem Pós-Keynesiana *
}

\section{Luiz Fernando de Paula}

Professor - Faculdade de Ciências Econômicas - Universidade do Estado do Rio de Janeiro (UERJ) Endereço para contato: Rua São Francisco Xavier, 524, sala: 8039-F - Rio de Janeiro - RJ CEP: 20550-013 - E-mail: luizfpaula@terra.com.br

Recebido em 08 de outubro de 2012. Aceito em 30 de janeiro de 2013.

\section{Resumo}

Este artigo analisa o papel do sistema financeiro para o crescimento econômico e o conceito de funcionalidade do sistema financeiro na visão pós-keynesiana. Argumenta-se que nessa perspectiva teórica um sistema financeiro funcional é aquele com poder de criação de crédito para atender a demanda de liquidez necessária para realização dos gastos pelos agentes, e com capacidade de criar mecanismos financeiros apropriados para realização da consolidação de dívidas das firmas inversoras. Assim, ele pode permitir um ritmo de acumulação a um nível superior àquele que seria viável pela simples acumulação de poupanças prévias. O artigo destaca ainda que o conceito de funcionalidade do sistema financeiro supõe a existência de uma estrutura diversificada de instituições e instrumentos financeiros que possa oferecer alternativas de financiamento para os agentes (principalmente firmas) realizarem seus gastos.

\section{Palavras-Chave}

sistema financeiro, crescimento econômico, teoria pós-keynesiana

\begin{abstract}
This paper analyzes the role of the financial system to economic growth, and the concept of 'functionality' of the financial system under a Post Keynesian approach. It argues that in such theoretical approach a functional financial system is that supplies credit in order to meet the agents' liquidity needs so that they can effectuate their expenditures, and at the same time is able to create suitable financial tools to fund the short term debts of the investors' firms. Therefore, such financial system can allow a higher capital accumulation rate that would be able by the simple accumulation of previous savings. The paper stresses that the concept of financial system functionality presumes the existence of a diversified structure of financial institutions and financial assets that are able to offer financing alternatives to the agents' (mainly firms) expenditures.
\end{abstract}

\section{Keywords}

financial system, economic growth, Post-Keynesian theory

\section{JEL Classification}

G21, E12, E44

- O autor agradece as sugestões de dois pareceristas anônimos, isentando-os de erros e omissões remanescentes. 


\section{Introdução}

Hoje em dia começa a ter uma maior aceitação no mainstream de que o sistema financeiro tem uma grande importância para o crescimento econômico, ainda que não exista um consenso sobre os requerimentos para um sistema financeiro operar de forma funcional a dar sustentação ao crescimento econômico, ainda que desde os anos 1950/60 tenha sido desenvolvida uma literatura que destacava a importância dos intermediários financeiros para o financiamento do investimento. ${ }^{1}$ A constatação em vários trabalhos empíricos (cf. Levine, 1997) de que há uma forte e robusta relação empírica entre essas variáveis não resulta na existência de uma teoria mais elaborada e convincente sobre o papel do sistema financeiro (setor bancário e mercado de capitais), seja em apoiar o desenvolvimento econômico, seja em dar origem a práticas e processos especulativos que possam resultar em crises financeiras. Franklin Allen (2001), em seu discurso presidencial na American Finance Association (AFA), observou a existência de uma visão amplamente aceita entre acadêmicos de que os intermediários financeiros podem ser ignorados uma vez que seu comportamento não têm efeito real na economia. Ele acrescenta que os intermediários financeiros são vistos como um véu, cujo comportamento não afeta os preços dos ativos ou a alocação de recursos.

A relação entre desenvolvimento financeiro e crescimento econômico foi "descoberta" no hoje influente artigo de Ross Levine (1997), bastante representativo da visão convencional, que destaca que "a preponderância de razões teóricas e evidências empíricas sugerem uma relação positiva e de primeira ordem entre desenvolvimento financeiro e crescimento econômico (...). O desenvolvimento dos mercados financeiros e instituições é uma parte crítica e inerente ao processo de crescimento, diferentemente da visão de que o sistema financeiro (....) responde passivamente ao crescimento econômico e industrialização" (Levine, 1997, p. 688-689). O autor, contudo, se utiliza do que denomina de "abordagem funcional" do sistema financeiro,

\footnotetext{
1 A análise sobre a importância da moeda e crédito para o crescimento e desenvolvimento econômico tem origem nos trabalhos de Keynes (1936/1985, 1937) e Schumpeter (1911/1982). Nos anos 1950/60, cabe destacar os trabalhos de Gurley e Shaw $(1955 ; 1960)$ e Patrick (1966), e nos anos 1970 o desenvolvimento da chamada "teoria da liberalização financeira" de Shaw (1973) e McKinnon (1973). Por sua vez, Minsky (1975, 1982), a partir de uma perspectiva pós-keynesiana, desenvolveu nos anos 1970/80 a chamada "teoria da fragilidade financeira". Nos anos 1990, a partir da análise da assimetria de informações, Stiglitz (1994, 1998) fez importantes contribuições sobre a relação entre Estado, crescimento e sistemas financeiros. Algumas dessas abordagens são tratadas nas seções seguintes deste artigo.
} 
onde instrumentos, mercados e instituições financeiras surgem para mitigar os efeitos dos custos de informação e de transação, isto é, "qualquer teoria sobre o papel do sistema financeiro no crescimento econômico (implícita ou explicitamente) adiciona fricções específicas ao modelo Arrow-Debreu" (Idem, p. 690; itálicos acrescentados).

Uma implicação importante desta abordagem é que o papel das instituições financeiras é o de mobilizar poupanças e facilitar a alocação de recursos, ou seja, cumprir o papel de intermediar recursos entre poupadores e investidores, e ao mesmo tempo facilitar o gerenciamento de riscos na atividade de intermediação. Não há uma grande diferença em relação à visão clássica dos intermediários financeiros desenvolvido nos anos 1950 por Gurley e Shaw (1955; 1960), no sentido de que ainda que tais intermediários tenham novas funções, além da intermediação propriamente dita, eles continuam a cumprir, em última instância, um papel relativamente neutro para o crescimento econômico. Ou seja, eles podem ajudar a mitigar o problema de informação imperfeita e assimétrica, reduzir os custos de transação na intermediação financeira ou ainda ajudar no gerenciamento de risco, mas não são os fatores determinantes deste processo.

A questão da importância do sistema financeiro para o desenvolvimento está há muito no cerne da teoria pós-keynesiana (Davidson, 1972; 1986; Minsky, 1982; 1986; Kregel, 1986; Carvalho, 1992) e tem suas raízes tanto no Treatise on Money de Keynes (1930), onde o mesmo desenvolve o embrião da teoria da endogeneidade da moeda, quanto na discussão de Keynes em 1937 com Ohlin e Robertson a respeito da relação entre financiamento, poupança e investimento, quando Keynes fez uma importante distinção entre poupança e financiamento, destacando o papel dos bancos na provisão de liquidez necessária para a realização do investimento.

Uma das diferenças fundamentais da teoria pós-keynesiana em relação à teoria econômica convencional é a importância fundamental, dada por esta abordagem, que moeda e instituições financeiras têm no funcionamento e dinâmica de uma economia empresarial. Em particular sistemas financeiros têm um papel crucial no crescimento econômico, independentemente da existência de problemas relacionados à existência de fricções no funcionamento dos mercados financeiros e de crédito. $\mathrm{Na}$ visão pós-keynesiana, o sistema financeiro tem um papel ambíguo na economia: ao mesmo tempo em que ele 
pode estimular o crescimento econômico como provedor de liquidez e na alocação da poupança ex-post para consolidar o investimento, a ação de especuladores nos mercados financeiros (necessária para prover liquidez nos mercados secundários) tem um papel instabilizador nesses mercados. Nesta abordagem, diferentemente da visão convencional, a poupança ex-ante não é condição prévia para a realização dos investimentos, e bancos - enquanto provedores de liquidez - têm um papel fundamental na criação de poder de compra novo para as firmas investidoras. Assim, a funcionalidade do sistema financeiro tem um sentido diferente da visão convencional, e isto tem importantes implicações de política.

Este artigo objetiva analisar a importância do sistema financeiro para o crescimento econômico e, em particular, o conceito de funcionalidade do sistema financeiro na visão pós-keynesiana, assim como as implicações do uso de tal conceito. Agregando-se a essa perspectiva, procuramos também secundariamente incorporar uma dimensão institucionalista de análise do financiamento e estruturas financeiras, na linha desenvolvida originalmente por Zysman (1983). Para o desenvolvimento da abordagem pós-keynesiana, o artigo tomou como ponto de partida trabalhos anteriores (Carvalho, 1997; Studart, 1995-96; Studart, 1999), procurando entretanto desenvolver/avançar os seguintes aspectos:

a) Busca-se mostrar que a "moderna teoria da intermediação financeira", mesmo reconhecendo a importância do sistema financeiro para o crescimento econômico, ainda mantém um papel relativamente neutro para as instituições financeiras enquanto intermediários financeiros;

b) Reconstituem-se as origens da teoria pós-keynesiana sobre financiamento e sistema financeiro, tomando como base artigos de Keynes escritos após a publicação da Teoria Geral (em 1936), em que ele analisa o processo de financiamento da formação da capital, ocasião em que faz uma distinção fundamental entre financiamento e poupança, destacando a importância do setor bancário na criação de poder de compra novo na economia;

c) Discutem-se os problemas relacionados à existência de um sistema financeiro não funcional ao crescimento econômico, potencializando a propensão a maior fragilidade financeira da economia; 
d) Avalia-se, com base na literatura, a questão de qual estrutura financeira é mais funcional em dar sustentação ao crescimento econômico, apontando para a significativa heterogeneidade entre países na relação entre desenvolvimento financeiro, estrutura financeira e crescimento econômico;

e) Destaca-se o papel ambíguo do sistema financeiro em economias monetárias: ao mesmo tempo em que sistemas financeiros desenvolvidos estimulam o crescimento econômico, estes podem ser fonte de forte instabilidade econômica, em particular em sistemas financeiros excessivamente desregulamentados, como mostrou a recente crise financeira internacional.

Além da presente introdução, o artigo está dividido em quatro seções. A seção 2 avalia a visão convencional sobre a relação entre financiamento e crescimento, enquanto que a seção 3 analisa tal relação a partir da perspectiva pós-keynesiana, enfatizando em particular o conceito de funcionalidade do sistema financeiro. A seção 4, por sua vez, analisa as estruturas financeiras alternativas e as mudanças recentes no sistema financeiro internacional. A seção 5 conclui o artigo.

\section{Visão Convencional do Sistema Financeiro}

A visão convencional sustenta que o sistema financeiro é um intermediário neutro de recursos na economia cuja existência é justificada principalmente por seu papel de diversificar as oportunidades entre poupadores e investidores, minimizar os custos de agenciamento entre emprestadores e tomadores, e de mitigar os efeitos dos custos de informação e de transação no processo de intermediação. ${ }^{2}$ Assim, custos de adquirir informação e fazer transações financeiras criam incentivos para a emergência de mercados e instituições financeiras. Em um mundo a la Arrow-Debreu, com informação perfeita, mercados completos sem fricções, instituições financeiras não seriam necessárias, uma vez que ofertantes e demandantes de fundos poderiam negociar diretamente. A ausência de informação perfeita sobre as oportunidades relacionadas aos investimentos produtivos faz com

2 Para uma resenha ampla, ver Gorton e Winton (2003). 
que as instituições financeiras tenham um papel no financiamento do investimento, uma vez que poupadores frequentemente não são capazes de selecionar as melhores oportunidades de investimento, ao mesmo tempo em que os investidores podem não encontrar as melhores oportunidades de aplicação de seus recursos em projeto de terceiros.

A teoria moderna da intermediação financeira tem sua origem na (hoje) "velha" abordagem de intermediação financeira de Gurley e Shaw $(1955,1960)$, que sustentava que o papel básico dos intermediários financeiros - enquanto transferidores de recursos das unidades superavitárias para as unidades deficitárias - é retirar do mercado uma parte (majoritária) dos títulos privados primários e substituí-los pela circulação de títulos secundários, de sua emissão. Neste sentido, "a função primária dos intermediários é emitir dívida contra si próprio, dívida indireta, em solicitar fundos emprestáveis das unidades de gastos superavitárias, e alocar esses fundos emprestáveis entre as unidades deficitárias cuja dívida direta eles absorveram" (Gurley e Shaw, 1955, p.518-519). ${ }^{3}$ Os autores fazem, portanto, uma distinção entre financiamento direto, no qual as unidades deficitárias emitem títulos primários diretamente às unidades superavitárias, e financiamento indireto, em que os intermediários financeiros, com base nos depósitos disponíveis (fornecido pelas unidades superavitárias) adquirem títulos primários das unidades deficitárias, que irão compor sua carteira com títulos, concedendo-lhes um crédito. Para eles, o financiamento direto era uma forma limitada de financiamento devido à dificuldade de avaliação de riscos por parte dos poupadores. Nesta abordagem, a funcionalidade do sistema financeiro pode ser vista como relacionada à alocação eficiente de recursos poupados entre as diversas oportunidades de investimento produtivo, sendo o volume desses recursos determinado externamente ao sistema, ${ }^{4}$ proporcionando uma maior flexibilidade e eficiência na transferência de fundos na economia, inclusive no que se refere à

3 Segundo Patrick (1966, p.182) "intermediários financeiros têm uma importante função em prover mecanismos de mercado para a transferência de direitos sobre recursos reais de poupadores para mais eficientes investidores. Quanto mais perfeitos forem os mercados financeiros, mais perto se estará da alocação ótima do investimento".

4 Está subentendido que o volume dos depósitos bancários é uma decisão de alocação intertemporal de renda e riqueza dos agentes. Isto fica claro nesta passagem de Gurley e Shaw (1955, p.521, grifos acrescentados), "nem bancos nem outros intermediários financeiros criam fundos emprestáveis. Isto é a prerrogativa de unidades de gasto com superávits sobre a renda (...) Bancos e outros intermediários tem a capacidade de criar formas especiais de ativos financeiros que unidades superavitárias podem acumular como recompensa para restringir seus gastos correntes ou de capital". 
diminuição do risco para poupadores (Studart, 1999, p.154). Assim, os intermediários financeiros têm uma função especial na economia, de atuar como transformadores de maturidades, compatibilizando as necessidades de financiamento dos investidores com desejos de poupança dos poupadores, ao transformarem ativos ilíquidos e de mais longa maturidade (empréstimos) em ativos líquidos de maturidades mais curta (depósitos).

A teoria moderna da intermediação financeira, por sua vez, está fundamentada na existência de falhas de mercados decorrentes da presença de informação assimétrica e/ou imperfeita, desviando assim do paradigma clássico de mercados perfeitos. Deste modo, as instituições financeiras têm como função principal a redução de custos de transações decorrentes das assimetrias informacionais e sua funcionalidade deriva da correção de tais falhas. Tais instituições têm informação privilegiada - o que lhes conferem uma vantagem comparativa sobre os mercados de capitais - o que lhes permitem monitorar de forma eficiente os tomadores de crédito, minimizando os custos de agenciamento entre tomadores e emprestadores de recursos.

Várias são as variantes na teoria moderna da intermediação financeira. ${ }^{5}$ A abordagem de assimetrias de informação (Leland e Pyle, 1977; Diamond, 1984; Stiglitz e Weiss, 1981) tem como ponto de partida que o tomador de empréstimos é provável ter mais informação que o emprestador sobre os riscos associados aos empréstimos, gerando problemas de risco moral e seleção adversa, o que pode reduzir a eficiência na transferência de fundos entre unidades superavitárias para unidades deficitárias. Bancos podem formar relações de longo prazo com as firmas, e através de monitoramento contornar parcialmente os problemas de risco moral e seleção adversa, que são inerentes à atividade de intermediação financeira. ${ }^{6}$ Assim, se o banco tiver uma

${ }^{5}$ Como será visto a seguir, as diferentes abordagens se assemelham em vários aspectos, normalmente se diferenciando pela ênfase no papel atribuído ao intermediário financeiro. Para um aprofundamento, ver as resenhas feitas por Gorton e Winton (2004) e Modenesi (2007).

6 O problema de seleção adversa ocorre quando, em decorrência de um aumento dos juros, bons tomadores que têm projetos menos arriscados são deslocados do mercado de crédito por maus tomadores, cuja probabilidade de ficar inadimplente é maior. Isto porque, a partir de determinado nível de juros, somente os projetos potencialmente mais rentáveis, porém mais arriscados, podem remunerar o empréstimo. Assim, o banco não consegue distinguir com precisão um tomador de alto risco de um de baixo risco. Como resultado, a razão entre bons e maus demandantes de crédito se reduz, ampliando a probabilidade de que maus tomadores sejam (adversamente) selecionados pelo banco. Já o problema do risco moral sustenta que a fixação da taxa de juros acima de um determinado patamar induz os investidores 
relação próxima com seus tomadores, isto o capacita a ter boas informações sobre os prospectos futuros dos projetos financiados, permitindo inclusive um melhor acompanhamento destes. Argumenta-se que os bancos podem assim reduzir o grau de informação imperfeita e assimétrica entre ofertantes e usuários dos fundos, uma vez que nem todos os poupadores têm tempo, inclinação ou expertise para monitorar o risco de default dos tomadores de crédito. Portanto, a teoria de monitores delegados sustenta que as instituições financeiras são coalizões de agentes que avaliam projetos, investem em determinados projetos de alto valor e dividem os retornos sobre o seu portfólio de projetos; beneficiam-se, assim, de ganhos de escala na atividade de monitoramento, reduzindo o custo de obtenção e/ou processamento de informações. Atuam, assim, como monitores delegados em benefício dos poupadores - ou seja, são agentes aos quais os emprestadores (depositantes) delegam a função de monitorar o comportamento dos devedores, com o objetivo de assegurar que os empréstimos sejam honrados. Uma das vantagens dos intermediários financeiros é sua capacidade de diversificação, que diminui os custos de intermediação. Portanto, os intermediários produzem informação sobre investimentos potenciais, informação esta que não pode ser produzida de forma eficiente no mercado de títulos, além de diminuir a dispersão do retorno dos empréstimos dos bancos.

Já a abordagem de custos de transação (Bernston e Smith, 1976; Campbell e Kracaw, 1980; Fama, 1980) sustenta que as instituições financeiras funcionam como uma coalização de agentes que busca explorar economias de escala derivadas do uso de tecnologias de transação (operação do sistema de pagamentos) e economias de escopo em função da sua diversificação de portfólio (por exemplo, portfólio de empréstimos). Bancos fornecem liquidez aos ativos financeiros e diversificam oportunidades para poupadores e investidores, sendo que sua funcionalidade repousa na redução dos custos de transação da atividade de financiamento (custo monetário de uma transação financeira, custo de monitoramento, custo de busca e auditoria). Esta teoria supõe que na ausência da existência do banco, a estrutura de custo/retorno do poupador e do tomador de crédito seria

a realizar projetos mais rentáveis (mas mais arriscados) para que possam remunerar seus empréstimos, resultando em uma ampliação da probabilidade dos devedores ficarem inadimplentes. Em ambos os casos, para evitar uma elevação no risco de sua carteira de crédito, os bancos mantêm a taxa de juros abaixo do equilíbrio e racionam crédito. Ver, a respeito, Stiglitz e Weiss (1981). 
maior, em função do maior custo de transação. ${ }^{7}$ Em outras palavras, bancos reduzem os custos de busca através de seus canais de distribuição (rede de agências, internet, telefone etc.), além de poderem reduzir os custos de negociação através do uso de contratos padrões de crédito (Mathews e Thompson, 2008, p.38-39). Em particular, firmas menores e menos conhecidas utilizam os bancos como fonte de financiamento devido aos custos relativamente menores junto com a vantagem da capacidade superior dos bancos de monitoração e seleção.

A abordagem da regulação, por sua vez, é desenvolvida por Guttentag e Lindsay (1968), Fama (1980), Mankiw (1986) e Merton (1995), dentre outros. Ela destaca a importância das regulações incidentes sobre a criação de moeda e os processos de poupança e de financiamento em uma economia capitalista. A regulação afeta a solvência e liquidez da instituição financeira, já que os bancos, em particular, por sua atividade típica de transformadores de maturidades se defrontam com o risco de insolvência e iliquidez. Neste sentido, Diamond e Rajan (2000) mostram que o capital próprio de um banco afeta sua capacidade de financiamento bem como sua capacidade de receber (os pagamentos) de seus tomadores, ou o desejo de liquidá-los. Segurança e robustez do sistema financeiro com um todo justificam a regulação da indústria financeira. Contudo, a regulação de intermediários financeiros, especialmente dos bancos, é custosa, devido aos custos diretos de administração e de emprego de supervisores, além de custos indiretos gerados pela supervisão prudencial, mas pode gerar rendas para os intermediários regulados no caso de aumentar as barreiras de entrada e saída do mercado. Em suma, considera-se que o marco regulatório é fundamental na atividade de intermediação financeira e estabilidade do sistema financeiro.

Por fim, a abordagem de gerenciamento de risco (Allen e Santomero, 1997, 1999; Scholtens e Wensveen, 2000; 2003), a função principal dos intermediários financeiros é o gerenciamento de risco em suas diferentes formas - maturidade, inadimplência, mercado (taxa de juros e preços dos ativos), etc. A absorção de risco é uma função central dos bancos e das companhias de seguro, permitindo reduzir as incompatibilidades entre poupadores (em média mais avessos ao risco) e investidores (menos avessos ao risco). O pressuposto básico

7 Cabe destacar que esta abordagem é a que mais deriva diretamente do enfoque de intermediação financeira de Gurley e Shaw, na realidade ampliando (e sofisticando) as funções dos intermediários financeiros. 
de tal abordagem é que os intermediários financeiros gerenciam riscos de forma mais eficiente e menos custosa do que os demais agentes econômicos. Os intermediários financeiros têm capacidade de absorver riscos uma vez que sua escala permite uma diversificação da carteira de investimentos, entendida como necessária para oferecer segurança requerida pelos poupadores. Desse modo, os intermediários financeiros não são apenas agentes que selecionam e monitoram os tomadores de crédito em nome dos poupadores, constituindo-se na realidade em contraparte ativa que oferecem um produto específico que não pode ser oferecido pelos investidores individuais aos poupadores, que é a cobertura de risco. Para tanto, eles usam sua reputação e suas operações de balanço e fora do balanço (Scholtens e Wensveen, 2003).

Assim, na perspectiva de teoria moderna de intermediação financeira, um sistema financeiro funcional seria aquele que provê a melhor distribuição de informação para guiar consumidores e poupadores na alocação intertemporal da renda e riqueza, contribuindo para superar (parcialmente) a assimetria de informações entre poupadores e investidores, o que contribui para um melhor gerenciamento de risco na atividade de intermediação financeira. Ao mesmo tempo, permite reduzir os custos de transação na atividade de intermediação, concorrendo, assim para a melhor alocação de recursos disponíveis para impulsionar o crescimento (Levine, 1997; Merton, 1993; Schoeltens e Wensveen, 2003).

O Quadro 1 sintetiza as funções do intermediário financeiro nas diferentes abordagens teóricas tratadas nesta seção. 
Quadro 1 - Função dos intermediários financeiros nas diferentes abordagens

\begin{tabular}{|c|c|}
\hline Abordagem & Função \\
\hline $\begin{array}{l}\text { "Velha" teoria da intermediação } \\
\text { financeira }\end{array}$ & $\begin{array}{l}\text { "A função primária dos intermediários é emitir dívida contra si próprio, dívida indireta, } \\
\text { em solicitar fundos emprestáveis das unidades de gastos superavitárias, e alocar esses } \\
\text { fundos emprestáveis entre as unidades deficitárias cuja dívida direta eles absorveram". }\end{array}$ \\
\hline Assimetria de informação & $\begin{array}{l}\text { Bancos podem formar relações de longo prazo com as firmas, e através de } \\
\text { monitoramento contornar parcialmente os problemas de risco moral e seleção adversa, } \\
\text { que são inerentes à atividade de intermediação financeira. Instituições financeiras são } \\
\text { assim coalizões de agentes que se beneficiam de ganhos de escala na atividade de } \\
\text { monitoramento, reduzindo o custo de obtenção e/ou processamento de informações, } \\
\text { atuando como monitores delegados em benefício dos poupadores ao monitorarem o } \\
\text { comportamento dos devedores. }\end{array}$ \\
\hline Custos de transação & $\begin{array}{l}\text { Instituições financeiras funcionam como uma coalização de agentes que busca explorar } \\
\text { economias de escala derivadas do uso de tecnologias de transação e economias de } \\
\text { escopo em função da sua diversificação de portfólio; ou seja, bancos fornecem liquidez } \\
\text { aos ativos financeiros e diversificam oportunidades para poupadores e investidores, } \\
\text { sendo que sua funcionalidade repousa na redução dos custos de transação da atividade } \\
\text { de financiamento. }\end{array}$ \\
\hline Regulação & $\begin{array}{l}\text { Destaca a importância das regulações incidentes sobre a criação de moeda e os } \\
\text { processos de poupança e de financiamento na economia, uma vez que a regulação } \\
\text { afeta a solvência e liquidez da instituição financeira, dado que os bancos em particular } \\
\text { por sua atividade típica de transformadores de maturidades se defrontam com o risco } \\
\text { de insolvência e iliquidez. }\end{array}$ \\
\hline Gerenciamento de risco & $\begin{array}{l}\text { A função principal dos intermediários financeiros é o gerenciamento de risco em suas } \\
\text { diferentes formas - maturidade, inadimplência e mercado. Os intermediários financeiros } \\
\text { gerenciam riscos de forma mais eficiente e menos custosa do que os demais agentes } \\
\text { econômicos, pois sua escala de operação permite uma diversificação da carteira de } \\
\text { investimentos, entendida como necessária para oferecer segurança requerida pelos } \\
\text { poupadores. }\end{array}$ \\
\hline
\end{tabular}

Fonte: Elaboração do autor.

Uma característica comum entre a "velha" e "nova" teoria da intermediação financeira é que ambas as abordagens não fazem distinção entre o comportamento de um banco analisado individualmente e o conjunto do sistema bancário, e ainda, consequentemente, o montante dos empréstimos dos bancos está limitado ao recebimento de depósitos prévios, cujo volume é uma decisão de alocação intertemporal de renda e riqueza dos agentes. Está implícita a visão de que o volume de recursos disponíveis para investimento depende da poupança prévia acumulada, uma vez que o financiamento é obtido pelo investidor quando o banco realiza a intermediação da poupança de algum agente poupador, provendo assim ao investidor recursos disponíveis para a acumulação de capital. Em outras palavras, o banco é uma espécie de intermediário neutro de recursos na economia, no sentido de que seu comportamento não afeta de forma decisiva as condições de financiamento da economia, uma vez que não tem 
capacidade de criar liquidez (poder de compra novo) que permita sancionar as decisões de gastos dos agentes. A abordagem pós-keynesiana, que será vista a seguir, tem uma visão bastante distinta do processo de financiamento e do papel dos bancos na economia.

\section{Funcionalidade do Sistema Financeiro ao Crescimento Econômico: A Abordagem Pós-Keynesiana}

A análise de Keynes sobre a atividade bancária e o financiamento da economia foi desenvolvida antes e depois da publicação da Teoria Geral. No seu Treatise on Money da Moeda, Keynes (1971) sustentou que a moeda toma a forma de moeda-crédito, e que os depósitos bancários são criados no processo de concessão de crédito e não necessariamente primeiro coletados a partir de depósitos existentes. ${ }^{8}$ Em outras palavras, a atividade bancária consiste na criação de liquidez, e não na mera transferência de recursos de agentes superavitários para agentes deficitários, para usar a terminologia consagrada de Gurley e Shaw. No Treatise on Money a oferta de moeda é tratada como endógena, uma vez que um aumento na quantidade da moeda para atender o crescimento no produto total requer a aquiescência do setor bancário.

O assunto é retomado na discussão pós-Teoria Geral com Ohlin e Robertson sobre a determinação da renda e mais especificamente sobre a relação entre poupança, financiamento e investimento (Keynes, 1937, 1939). Não se pretende aqui resgatar tal discussão, ${ }^{9}$ mas assinalar que Keynes reafirmou o papel central dos bancos na atividade econômica e no financiamento do investimento e a natureza endógena do processo de criação da moeda bancária: "o financiamento [das empresas] requerido durante o interregno entre a intenção e a implementação do investimento é ofertada principalmente por especialistas, em particular por bancos" (Keynes: 1937: 666). Em uma conhecida passagem de um de seus textos, Keynes (1937) fez uma

8 É importante ressaltar que tal concepção faz sentido quando se considera o setor bancário não como um todo e não apenas o banco individualmente. Isto porque quando banco concede crédito para o cliente, ele cria ao mesmo tempo um crédito (empréstimos) e débito (depósitos); tais depósitos, por sua vez, são utilizados pelo cliente para efetuar gastos e correspondente pagamento, no que resulta em depósitos em outro banco, que por sua vez concede crédito correspondente a esses, e assim sucessivamente. Assim, para o setor bancário como um todo o volume total de depósitos é igual ao volume de crédito concedido.

9 Ver, a respeito, Carvalho (1996). 
importante distinção entre financiamento e poupança, e assinalou que o investimento nunca deixará de ser realizado por falta de poupança, mas sim por falta de financiamento:

Os bancos detêm uma posição chave na transição de uma escala inferior de atividade para uma mais elevada. Se eles recusam a uma acomodação, um crescente congestionamento do mercado de empréstimos de curto prazo ou do mercado de novas emissões inibirá a melhora (nas condições de financiamento), não importa quão frugal o público se proponha a ser a partir de suas rendas futuras. (....) O mercado de investimentos pode tornar-se congestionado por causa da falta de liquidez, mas nunca se congestionará por falta de poupança. (Keynes, 1937, p.668-669)

Com é sabido, para Keynes (1936, 1937, 1939), em uma economia empresarial a poupança não é pré-condição para investimento, e a igualdade entre poupança e investimento resulta da mudança no nível de renda, sendo que a decisão de investimento precede logicamente a criação da renda. Seguindo o princípio da demanda efetiva, que sustenta que são os gastos agregados que geram a renda na economia, a poupança (ex-post) não pode financiar nada, pois representa apenas a renda não consumida, inexistente antes da realização do investimento. Investimento é determinado primariamente pelas expectativas empresariais de longo prazo relacionadas às rendas futuras de seus ativos de capital. Em um mundo incerto, o sucesso dos negócios depende crucialmente da confirmação das expectativas empresariais, mas isto não ser prognosticado antecipadamente. Assim, investimentos só serão realizados se o "espírito animal" dos empresários estiver desperto, e também se houver disponibilidade de crédito por parte do setor bancário. Em tal economia, o financiamento, que é independente da poupança prévia, precede o investimento:

É claro que nada é mais seguro do que o fato de que o crédito ou o 'financiamento' requerido pelo investimento ex ante não é principalmente fornecido pela poupança ex ante. Que partese é que alguma - é desempenhada por essa poupança, iremos considerar em algum momento. (Keynes, 1937, p.664) 
Assim, seguindo o princípio da demanda efetiva, a poupança é o resultado do processo de geração de renda na economia (e não o seu início), não se constituindo em um obstáculo para o investimento: se existe financiamento que permita que o investimento seja realizado, as variações do gasto do investimento provocam variações de tal magnitude na renda agregada que induzem uma variação da poupança desejada pelas famílias no mesmo montante da variação inicial do investimento. Logo, o acréscimo do investimento é financiado fora das poupanças resultantes do processo de geração de renda; não somente o investimento gera a renda maior do que a inicial, como ele também é financiado independentemente da poupança prévia. De fato, a oferta de fundos disponíveis não é determinada pela canalização do fluxo de poupança do período, mas sim pelo estoque de ativos financeiros existentes. Assim, o que se requer para gerar fundos para financiar investimentos é a renúncia à liquidez dos agentes, de modo a adquirir novos títulos ofertados pelos demandantes de fundos, adicionada à capacidade de criação ativa de crédito por parte do setor bancário. Nas palavras de Keynes:

Poupança em uma data prévia não poderá ser maior do que o investimento naquela data. $\mathrm{O}$ maior investimento será sempre acompanhado de maior poupança, mas nunca será precedido por ela. Desentesouramento e expansão de crédito provêm não uma alternativa para uma maior poupança, mas uma necessária preparação para ela. Ele é o pai, e não o gêmeo do aumento da poupança. (Keynes, 1939, p. 572, grifos no original)

A oferta agregada de financiamento em uma economia monetária é determinada principalmente pelo desejo dos bancos criarem crédito e depósitos correspondentes, e ainda pelo estoque de moeda existente. Keynes (1937), ao analisar o processo de financiamento da formação de capital, descreveu este como tendo duas etapas: uma primeira, na qual a provisão de moeda permite que a despesa de investimento seja implementada (finance), ou seja, a demanda por moeda provida pelo setor bancário no momento em que a firma decide investir; e uma segunda, na qual a poupança ex post é utilizada para consolidar dívidas para a despesa de investimento. $\mathrm{O}$ funding é o processo de transformação de dívidas de curto prazo em obri- 
gações de longo prazo, de modo a tornar compatível a maturidade e montante das obrigações da firma investidora vis-à-vis o retorno esperado dos investimentos.

Keynes sugeriu em sua análise um circuito que envolve financiamento-investimento-poupança-funding, em que a obtenção de financiamento (moeda) é o início do processo de formação de capital, a poupança é gerada a partir das decisões de investimentos, como resultado do processo multiplicador de renda, enquanto que a poupança ex post poderia ser canalizada para o mercado financeiro para consolidar a dívida de curto prazo das firmas investidoras. Os requerimentos financeiros do processo de formação de capital podem então ser sumarizados da seguinte forma:

O empresário quando decide investir, tem que se satisfazer em dois pontos: primeiro, deve poder obter um financiamento de curto prazo suficiente durante o período de produção do investimento; e, em segundo lugar, deve poder eventualmente consolidar, em condições satisfatórias, as obrigações de curto prazo, através de emissões de títulos de longo prazo. Vez ou outra, o empresário pode utilizar-se de recursos próprios ou fazer emissão de longo prazo diretamente, mas isso não modifica o volume de financiamento, que tem que ser encontrado pelo mercado como um todo, mas apenas o canal pelo qual chega o empresário e a probabilidade de que parte do volume possa ser levantada pela liberação de dinheiro do próprio bolso ou do resto do público. Dessa forma, é conveniente ver o processo duplo como o característico" [no financiamento do investimento]. (Keynes, 1937, p. 664)

A compra de um bem de capital por parte do investidor, necessária para a materialização do investimento, requer - tal como qualquer outra transação - o acesso à moeda. Em particular, a realização de qualquer gasto planejado requer a criação de moeda, independentemente da natureza do bem transacionado. Keynes chamou de demanda de financiamento (finance) a demanda por moeda que permite a compra de bens de investimento. Finance é um fundo rotativo 
que não requer a existência prévia de poupança. Se o fluxo de gastos agregados permanece constante, dada a velocidade constante da moeda, o estoque de moeda existente pode financiá-los pela simples troca de mãos de moeda entre agentes na realização das transações, não sendo necessários que os bancos criem novos empréstimos. ${ }^{10}$ Contudo, se os gastos agregados vão ser aumentados - por exemplo, se o investimento se expandir gerando uma demanda de moeda para o motivo finance superior aos recursos monetários gerados no período anterior - então é necessária a criação de nova moeda, o que deverá ser feito pelo setor bancário e/ou por um desentesouramento por parte dos agentes em função de uma menor preferência pela liquidez por parte desses. Se os bancos suprem o crédito para satisfazer a demanda por moeda, via expansão de suas operações ativas e os agentes abrem mão de sua liquidez (comprando títulos ofertados pelos ofertantes de fundos), as taxas de juros não aumentarão com o aumento do nível de atividade econômica; caso isto não ocorra, alguns investimentos poderão não ser realizados por escassez de financiamento ou sua realização resultará em um aumento na taxa de juros. Quando o banco concorda fazer um empréstimo para um novo projeto de investimento, este empréstimo cria uma obrigação, um depósito correspondente. ${ }^{11}$ Se a autoridade monetária acomoda a demanda por reservas dos bancos que surge como um resultado da criação de depósitos via crédito, o finance é gerado. O empréstimo realizado é usado pela firma para pagar o ofertante do novo equipamento e contratar novos trabalhadores; firmas e trabalhadores, por seu turno, depositam sua renda no setor bancário. Assim, os bancos são capazes de financiar o investimento sem necessidade de poupança prévia. ${ }^{12}$

\footnotetext{
${ }^{10}$ Segundo Carvalho (1997, p.467, itálicos no original), "Bancos não têm que criar novos empréstimos. O próximo gastador em linha usará a moeda recebida para fazer seus pagamentos. Os depósitos totais não têm que se alterar para que novos pagamentos sejam feitos: eles somente mudam de mãos (...) [Assim] finance no conceito keynesiano não tem nada a ver com poupança ou com o multiplicador. Uma vez que estamos tendo um fluxo constante de gastos, o finance se constitui em um fundo rotativo".

${ }^{11}$ No Treatise on Money, Keynes (1930, p. 153) destaca que os próprios bancos "podem comprar ativos, ou seja, aumentar seus investimentos, e pagar por eles na forma de um crédito contra eles mesmos".

${ }^{12} \mathrm{~A}$ análise da dinâmica dos bancos e criação de moeda-crédito por esses corresponde ao Estágio $\mathrm{V}$ da evolução bancária sugerido por Chick (1992), ou seja, pressupõe-se a existência de um banco central em sua função de emprestador de última instância e o desenvolvimento de técnicas de administração de passivo por parte dos bancos.
} 
Uma das peculiaridades do investimento em relação a outros ativos é que ele é composto da compra de ativos de longa vida, o que coloca o problema de como consolidá-lo, ou seja, de como torná-lo compatível com o perfil temporal das obrigações da firma investidora. Os fundos para consolidação das dívidas de curto prazo das firmas em uma estrutura de ativos financeiros de mais longo prazo estão disponíveis uma vez que a poupança surge pari passu com o fluxo de investimentos. Embora a poupança seja criada simultaneamente com o investimento, isto não significa que ela se torna imediatamente e da forma apropriada disponível para consolidar as dívidas dos investidores. Ela pode, por exemplo, ser usada para comprar ativos de curto prazo, se a preferência pela liquidez dos agentes estiver aguçada e/ ou não houver instrumentos financeiros adequados para canalizar a poupança para ativos financeiros de longo prazo. A incerteza sobre as taxas de juros futuras pode gerar um sentimento de "urso" (bearish) no mercado de títulos que estimule os poupadores a se manterem líquido. Assim, o funding será dificultado, senão inviabilizado. Se não houvesse incerteza, o circuito finance-investimento-poupança-funding se completaria simultaneamente ao processo de multiplicação de renda; mas em um mundo incerto, o desenvolvimento completo do multiplicador não garante a alocação de poupança nos títulos de longo prazo ou na compra de ações (Studart, 1999). Assim, o problema fundamental de uma economia empresarial não é como gerar a poupança, mas como fazer com que a poupança disponível esteja disponível para permitir a consolidação das dívidas dos investidores.

O risco de não ser capaz de consolidar a dívida fica nas mãos do investidor que tomou empréstimos curtos para investir em ativos de longa vida. Alternativamente, o investidor pode colocar títulos próprios de longo prazo (ações ou títulos de dívida corporativa) diretamente no mercado financeiro, ou indiretamente vendendo seu título para um banco de investimento, que mais tarde coloca seu próprio título no mercado (Carvalho, 1997, p. 473).

Do ponto de vista macroeconômico, o funding tem um o papel de mitigar o crescimento da fragilidade financeira que é inerente a uma economia em crescimento, devido tanto ao aumento no grau de endividamento dos investidores quanto ao descasamento de maturidades entre sua estrutura ativa e passiva (Minsky, 1986). Mercados financeiros têm um importante, mas, ao mesmo tempo, ambíguo papel de dar suporte ao crescimento sustentado. Por um lado, eles podem aju- 
dar a transformar as maturidades das firmas quando tais mercados são capazes de fazer a mediação entre os demandantes de títulos e as firmas desejosas de consolidar suas obrigações de curto prazo em dívidas de longo prazo. Cabe às instituições e mercados financeiros o papel de diversificar ativos a serem ofertados aos poupadores e administrar as estruturas passivas e ativas com horizontes de maturação distintos. ${ }^{13}$ Assim, a falta de mercados financeiros organizados e bem desenvolvidos pode fazer com que o financiamento tenda a ser de mais curto prazo e o racionamento de crédito pode ocorrer em tempos de crescimento, diminuindo a capacidade de expansão da economia. Consequentemente, a posição financeira de firmas e bancos torna-se mais frágil (Studart, 1995-96, p. 283). Por outro lado, os mercados financeiros podem ser uma fonte de instabilidade criada a partir da ação de especuladores. Tal comportamento é necessário para dar liquidez aos títulos no mercado secundário, pois este só existe se houver agentes apostando em direção contrária em relação aos preços dos ativos. Contudo, quando a ação dos especuladores domina os mercados financeiros, as práticas de curto prazo determinam o ritmo dos preços dos ativos.

A especulação é uma atividade de prever a psicologia do mercado. Em uma economia empresarial, a organização de mercados financeiros enfrenta um trade-off severo entre liquidez e especulação, como Keynes apontou na capítulo 12 de sua Teoria Geral. Em suas palavras:

(...) a maioria dessas pessoas está, de fato, muito preocupada não em fazer uma avaliação superior de longo prazo de um provável rendimento de um investimento em sua vida útil total, mas em prever mudanças na base convencional de avaliação em um curto tempo a frente do público geral. Elas estão preocupadas não no que o investimento irá valer para a pessoa que o compra 'para mantê-lo', mas naquilo que o mercado irá estimar, sob a influência da psicologia de massa, três meses ou um ano a frente. (Keynes, 1936/2007, p.154-5)

${ }^{13}$ Cabe ressaltar que o problema de transformação de maturidade aqui analisado, que é a base da teoria de fragilidade financeira de Minsky, refere-se às firmas investidoras que tendem a se alavancar durante o boom cíclico, impulsionadas pela política mais acomodatícia na concessão de crédito por parte dos bancos. Para um aprofundamento, ver Alves Jr et al. (2008). 
A função primária dos mercados financeiros secundários é prover liquidez aos ativos financeiros, que envolve a habilidade de comprar e revender ativos em um mercado bem organizado, em que estes ativos financeiros podem ser prontamente revendidos. Uma vez que os mercados provêm liquidez aos ativos, esta característica facilita o uso desses ativos para financiar o investimento, assim como podem encorajar os poupadores a proverem o funding necessário que estimula as firmas a gastarem seus recursos monetários em novos projetos de investimentos produtivos. ${ }^{14} \mathrm{~A}$ canalização da poupança para títulos de maturidade mais longa tem o papel de equilibrar as posições patrimoniais do investidor em função do já mencionado descasamento entre a maturidade da dívida bancária de curto prazo e a vida útil do ativo de capital. ${ }^{15}$

Um sistema financeiro não funcional ao crescimento econômico pode ter consequências desfavoráveis para a dinâmica de crescimento da economia. De fato, em períodos marcados por expectativas pessimistas de longo prazo (Keynes, 1936/2007, cap.12), qualquer progresso no processo de crescimento econômico tende a ser evitado tanto porque o investimento espontâneo é limitado quanto pela falta de fontes adequadas de financiamento na economia. Na ausência de instituições e mercados financeiros desenvolvidos, em período de expectativas otimistas, em função da escassez de fontes apropriadas de financiamento, os investimentos planejados podem ser financiados por alguma combinação entre ações, crédito de curto prazo e, em função da disponibilidade e condições, de empréstimos externos. Neste caso, a estrutura inadequada de financiamento do investimento será caracterizada pelo maior grau de descasamento de prazos e moedas, e, consequentemente, de maiores riscos na economia e logo maior fragilidade financeira (Hermann e Paula, 2011). Assim, na ausência de um sistema financeiro funcional a um crescimento financeiramente estável, cada ciclo de crescimento será acompanhado de uma maior fragilidade financeira doméstica e/ou externa (Minsky,

14 Alternativamente, a falta de mercados secundários pode inibir o desenvolvimento de mercados financeiros. Ver, a respeito, Alves Jr. et al. (2000).

${ }^{15}$ Cabe destacar que o circuito financiamento-investimento-poupança-funding é válido também para analisar economias abertas, em que a importação de bens de capital é realizada através do finance obtido via recursos captados no sistema financeiro internacional, que poderão resultar na produção de bens de consumo para o mercado externo, detonando um processo multiplicador de gastos, no qual a poupança surge como resíduo ao final deste processo e é utilizada para realização do funding, completando assim o circuito (Resende, 2008). Ressalta-se que um funding mal feito neste caso resulta em uma situação de fragilidade financeira externa, já que o país fica vulnerável às mudanças nos condições de financiamento do sistema financeiro internacional (Paula e Alves Jr, 2000). 
1986; Paula e Alves Jr, 2000). ${ }^{16}$ Esta condição aumenta o risco do ciclo de crescimento ser interrompido devido a uma crise bancária e/ou crise cambial.

O conceito de "funcionalidade do sistema financeiro", a partir de uma perspectiva teórica pós-keynesiana, foi formulada por Studart (1995-96), para quem:

[Um] sistema financeiro é funcional para o processo de desenvolvimento quando ele expande o uso de recursos existentes no processo de desenvolvimento econômico com um mínimo aumento possivel na fragilidade financeira e outros desequilíbrios que possam deter o processo de crescimento por razões puramente financeiras. (Studart, 1995-96, p. 64)

Ou seja, um sistema financeiro funcional é aquele capaz de prover financiamento (finance) que permite aos empresários realizarem gastos com investimentos e que canaliza poupança para, direta ou indiretamente, fundar suas dívidas mais tarde (funding). ${ }^{17}$

Studart (1995-96) define a funcionalidade dos sistemas financeiros em duas dimensões. Na dimensão macroeconômica, a funcionalidade do sistema financeiro deve ser avaliada em quão bem ele desempenha as funções de finance e funding, ou seja, de como dá suporte a um crescimento financeiramente estável. Já na dimensão microeconômica, a funcionalidade do sistema financeiro está relacionada à habilidade de prover as funções acima ao menor custo possível. Assim, um sistema financeiro pode desempenhar razoavelmente suas funções de financiamento, mas mantendo altos custos de intermediação

\footnotetext{
${ }^{16}$ Para Minsky $(1975,1982)$, a própria dinâmica do processo de crescimento econômico leva as firmas a se tornarem crescentemente endividadas para expandir o investimento. Existe, assim, uma tendência inerente das estruturas financeiras capitalistas em se moverem de estado de robustez para um estado de fragilidade ao longo do tempo. Isto ocorre em função das mudanças nas expectativas dos agentes que ocorre ao longo do ciclo econômico, e a forma como esta mudança é transmitida através do sistema financeiro. As flutuações cíclicas da economia resultam da maneira como as firmas financiam suas posições de carteira, com a fragilidade se elevando em períodos de crescimento devido ao aumento do número de agentes com posturas especulativas.

${ }^{17}$ Note-se que esta abordagem se diferencia da abordagem funcional do sistema financeiro de Levine (1997), em que - como vimos anteriormente - instrumentos, mercados e instituições financeiras surgem para mitigar os efeitos dos custos de informação e de transação.
} 
ou financiamento projetos de futuro duvidosos; alternativamente, ele pode ser tecnologicamente sofisticado e eficiente operacionalmente, mas altamente ineficiente do ponto de sua funcionalidade macroeconômica. ${ }^{18}$

Existe claramente uma dimensão de Keynes (resolver o problema de financiamento dos investimentos) e uma dimensão de Minsky (redução da fragilidade financeira da economia) envolvida no conceito de funcionalidade do sistema financeiro. De fato, a funcionalidade do sistema financeiro não está relacionada a simplesmente estimular cada round do desenvolvimento econômico, mas sim se trata de uma condição fundamental para o crescimento de longo prazo. Uma importante consequência da abordagem teórica aqui desenvolvida é que embora as decisões de investimento sejam determinadas pelas expectativas empresariais de longo prazo, o desenvolvimento do sistema financeiro é muito importante para dar suporte ao desenvolvimento econômico. Não se pode esperar que tais instrumentos financeiros sejam criados espontaneamente por mercados financeiros privados, especialmente no caso de países em desenvolvimento.

\section{Estruturas Financeiras Alternativas e Mudanças Recentes no Sistema Financeiro}

Quando sugeriu o esquema de financiamento finance-funding, Keynes estava pensando em um sistema financeiro com especialização institucional do tipo anglo-saxão, então vigente na Inglaterra e nos EUA, onde se tem uma dicotomia entre bancos, criadores de

\footnotetext{
${ }^{18}$ Uma dimensão importante da funcionalidade do sistema financeiro destacada pela teoria pós-keynesiana - mas que não será aqui aprofundada - é a eficiência alocativa, que trata de quem tem acesso ao crédito (indivíduos, firmas e regiões geográficas). Na abordagem de preferência pela liquidez, que busca entender a influência da moeda na desigualdade econômica regional (Dow, 1993; ver ainda, Menezes et al., 2007), distinguem-se duas regiões: uma periférica, marcada pela existência de uma economia estagnada e pouco desenvolvimento dos mercados, com predominância do setor primário, manufatura menos desenvolvida tecnologicamente em relação ao centro e baixo grau de sofisticação do sistema financeiro, características essas que determinam maior incerteza em relação ao desempenho econômico da região, implicando maior preferência pela liquidez; uma central, uma economia mais desenvolvida e diversificada, com a presença de um sistema financeiro mais sofisticado, onde se localizam as sedes das instituições financeiras, o que teria como resultado maior facilidade na concessão do crédito no centro. Cria-se, assim, um processo de causação cumulativa, em que a redução da preferência pela liquidez do centro permite reduzir a oferta de crédito na periferia, visto que a oferta se desloca para regiões onde haja maior demanda (Cavalcante et al., 2004).
} 
finance e mercados de capitais, em que as firmas investidoras podem emitir diretamente seus títulos corporativos com vistas à realização do funding, ou podem ainda se utilizar de intermediários financeiros (bancos de investimento) que levantam no mercado capital dos poupadores em nome das firmas investidoras que emitem ações ou títulos de dívida. Assim, nesse modelo (até pelo menos o processo de desregulamentação dos anos 1980 e 1990), os bancos comerciais são tipicamente os agentes principais no fornecimento de liquidez necessária para início do processo de investimento (finance), enquanto que os bancos de investimento desempenham o papel de auxiliar no processo de financiamento, realizando a subscrição dos títulos das empresas investidoras ou mantendo em carteira títulos (ações e títulos de dívida) das empresas financiadas. Para o desenvolvimento do mercado primário de títulos, entretanto, é fundamental a existência de um mercado secundário denso ${ }^{19}$ que dê liquidez aos títulos emitidos primariamente, pois isto estimula que os "poupadores" comprem títulos de maturidade mais longa. Como já ressaltado anteriormente, os especuladores têm um papel importante em dar liquidez aos mercados financeiros, ainda que sua ação possa instabilizar os preços em tais mercados. Cabe assinalar que a poupança adicional gerada pelo processo multiplicador de renda deverá ser canalizada através do mercado financeiro para que o funding das empresas possa ser realizado, mas para tanto é necessário a existência de instrumentos financeiros apropriados para tanto. O Quadro 2 mostra um fluxograma que sintetiza o circuito de financiamento em um sistema financeiro funcional ao crescimento econômico financeiramente estável em uma estrutura financeira baseada no modelo anglo-saxão.

${ }^{19}$ Um mercado secundário denso é aquele em que funcione um mercado de revenda que permita a venda de um título o mais prontamente possível com a menor perda possível em seu valor. 
Quadro 2 - Circuito de financiamento no modelo anglo-saxão

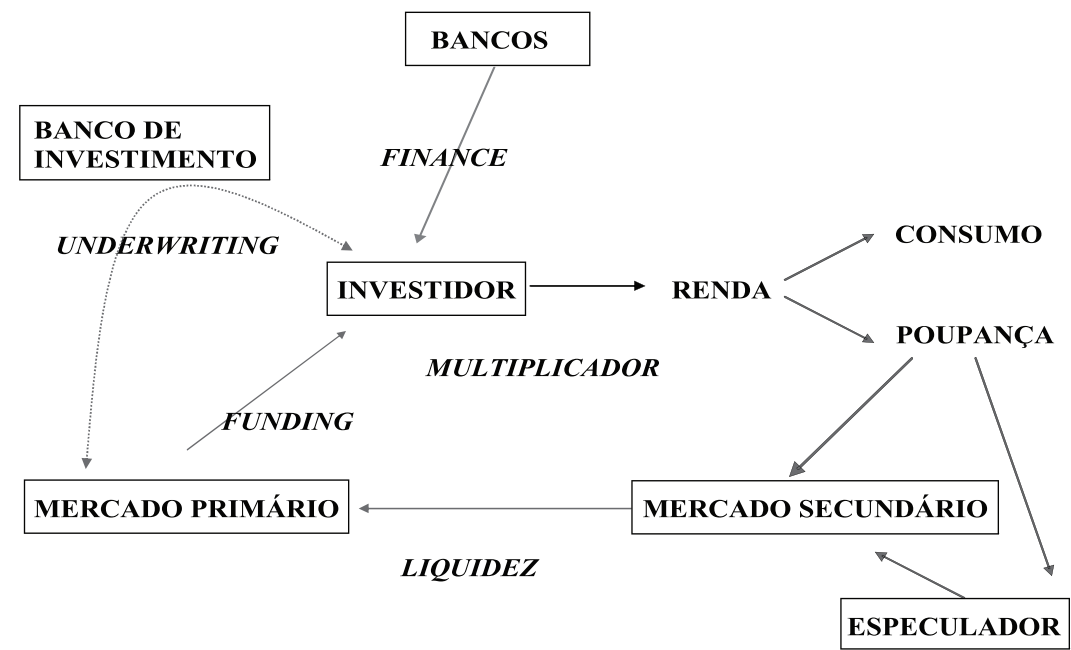

Fonte: Adaptado de Carvalho et al. (2007, p.334).

A validade do circuito de financiamento finance-funding, contudo, não depende de uma estrutura financeira especializada, como era típica até recentemente no sistema financeiro norte-americano. Em qualquer economia capitalista, o processo de formação de capital começa com a provisão de liquidez, através da oferta de financiamento (finance) e conclui com a geração e alocação da poupança para a realização do funding das empresas investidoras. Portanto, diferentes formas de organização do sistema financeiro devem constituir formas específicas que permitam que as duas funções - finance e funding - sejam realizadas (Carvalho, 1997, p.475-76). Assim, a funcionalidade de qualquer sistema financeiro não pode ser assegurada, nem qualquer política proposta, sem uma análise mais apurada das instituições existentes no país e seu papel em financiar a acumulação de capital. ${ }^{20}$

${ }^{20}$ Corbett e Jenkinson (1997), ao analisarem como o investimento físico tem sido financiado na Alemanha, EUA, Japão e Reino Unido, em 1970-94, concluem que em tais países a forma predominante de financiamento são fundos internos. Deve-se ressalvar, contudo, que os autores subtraem dos dados relativos ao mercado de ações valores relacionados ao uso de fluxo de caixa para compra de ações em operações de fusão e aquisição, além de operações de reestruturação de passivo. Em que pese a predominância de fundos internos para financiar o investimento, o ponto relevante para nossa análise é que na fase de expansão econômica as firmas tendem a se alavancar, i.e., cresce a participação de capital de terceiros nas suas 
No caso de sistemas financeiros não segmentados, também conhecidos como "modelo alemão", o mercado de capitais é débil e não se constitui em uma fonte importante de financiamento das firmas, havendo o predomínio da forma de financiamento indireto, com uma concentração das funções de provimento de liquidez e de financiamento de longo prazo para a realização do funding em uma única instituição bancária, conhecida como "banco universal". Esta atua simultaneamente como banco comercial e banco de investimento, internalizando em uma única instituição financeira serviços de diferentes espécies. Assim o banco universal desempenha ambas as funções (finance e funding), ainda que possa haver uma distinção interna entre tais funções. Na Alemanha, por exemplo, existiam limites estritos para o uso de fundos de curto prazo para comprar ou ofertar ativos de longo prazo por parte dos bancos, devendo os fundos de longo prazo ser obtidos pela colocação de títulos/certificados bancários.

A experiência dos países desenvolvidos mostra que não existe um modelo de sistema financeiro ideal para dar suporte ao desenvolvimento econômico. Na realidade, as características histórico-institucionais acabam por moldar em grande medida o desenvolvimento do sistema financeiro em cada país. Zysman (1983) sugeriu uma taxonomia, um pouco diferente da analisada acima (sistemas financeiros segmentados com especialização institucional e sistemas financeiros não segmentados), dividida em dois grandes tipos: sistema financeiro com base no mercado de capitais (capital market-based system) e sistema financeiro com base no crédito bancário (credit-based financial system): o primeiro tem uma importante participação de instrumentos diretos de financiamento (ações e títulos de dívida) como fonte de financiamento de longo prazo, a existência de instrumentos e mercados financeiros diversificados, e a presença de um mercado de crédito bancário de curto prazo; no segundo o mercado de capitais é fraco, normalmente há baixa especialização institucional e existe uma predominância do financiamento indireto, ou seja, do crédito bancário como principal forma de financiamento da economia. Sistemas financeiros com base no crédito podem ainda ser

obrigações. Usando uma metodologia distinta, Teixeira Filho e Macahyba (2012, p. 19), ao analisarem o padrão de financiamento da industrial e na infraestrutura no Brasil, constatam que em 2001-2010 os lucros retidos responderam em média por 48\% do total de financiamento, empréstimos do BNDES por 25\%, captações externas por 14\% e mercado de capitais (debêntures e ações) por 13\%, tendo crescido a partir de 2007 a participação do BNDES no total, ao mesmo tempo em que caiu a participação dos lucros retidos. 
subdivididos em dois tipos: sistema financeiro controlado por grandes grupos financeiros autônomos (tipo alemão) e sistema controlado por organismos de governo (tipo francês). O Quadro 3 apresenta algumas características das estruturas financeiras, de acordo com a taxonomia, já bastante consagrada, sugerida por Zysman.

Quadro 3 - Taxonomia dos sistemas financeiros, segundo Zysman

\begin{tabular}{|c|c|}
\hline Sistemas financeiros com base no mercado de capitais & Sistemas financeiros com base no crédito bancário \\
\hline $\begin{array}{l}\text { Estrutura financeira diversificada com especialização } \\
\text { das instituições em segmentos distintos do mercado }\end{array}$ & $\begin{array}{l}\text { - } \quad \text { Baixa especialização institucional e pouca } \\
\text { variedade de instituições financeiras }\end{array}$ \\
\hline $\begin{array}{l}\text { - Grande diversificação dos instrumentos e mercados } \\
\text { financeiros } \\
\text { - } \quad \text { Forte predomínio de formas diretas de financiamento }\end{array}$ & $\begin{array}{l}\text { - Mercado de capitais é pouco desenvolvido } \\
\text { - Forte predomínio de formas indiretas de } \\
\text { financiamento }\end{array}$ \\
\hline $\begin{array}{l}\text { - } \quad \text { Existência de mercados secundários bem organizados } \\
\text { e sólidos que permitam conferir liquidez aos títulos } \\
\text { - } \quad \text { Securities (ações e títulos) são principais fontes de } \\
\text { financiamento de longo prazo } \\
\text { Bancos atuam basicamente no segmento de crédito } \\
\text { de curto prazo (crédito pessoal e capital de giro) }\end{array}$ & $\begin{array}{l}\text { - Financiamento de investimentos assume a forma } \\
\text { predominante de empréstimos bancários de longo } \\
\text { prazo } \\
\text { - } \quad \text { Sistema financeiro controlado por organismos do } \\
\text { governo (tipo francês) } \\
\text { - Sistema financeiro controlado por grandes grupos } \\
\text { financeiros autônomos (tipo alemão) }\end{array}$ \\
\hline
\end{tabular}

Fonte: Elaboração própria com base em Zysman (1983).

Zysman (1983) assinalou que, do ponto de vista histórico, tanto o sistema baseado no mercado de capitais quanto o sistema baseado no setor bancário têm sido funcionais em dar sustentação ao crescimento econômico. Sua análise mostra ainda que nem todos os países combinaram desenvolvimento financeiro com crescimento econômico de forma sincronizada. Entre os países desenvolvidos, somente Reino Unido, EUA e Alemanha o fizeram, sendo que, como já destacado, nos dois primeiros casos com um sistema baseado no mercado de capitais, e no terceiro em um sistema baseado no crédito, organizado ao redor do banco universal. Todos os países industrializados ou em desenvolvimento que realizaram ou aprofundaram o seu processo de industrialização no pós- $2^{\mathrm{a}}$ Guerra Mundial tiveram como suporte um sistema financeiro baseado no crédito de algum modo controlado por organismos de governo, a cargo de grandes bancos públicos e/ou agências de desenvolvimento, muitas vezes em parceria com grandes 
bancos privados. ${ }^{21}$ Gerschenkon (1962) já havia assinalado que a industrialização de países "atrasados" não é um processo gradual e contínuo, sendo, em especial, necessária com frequência uma ação estatal mais efetiva em prol da industrialização. Sem dúvida, um dos mecanismos frequentemente utilizado para dar suporte ao desenvolvimento industrial tem sido o financiamento público. ${ }^{22}$

Vários estudos procuraram avaliar empiricamente a relação entre desempenho econômico e estrutura financeira, i.e, o grau no qual o sistema financeiro de um país é baseado no mercado ou baseado em bancos. ${ }^{23}$ Para tanto algumas hipóteses são levantadas na literatura convencional (Levine, 2002; Beck e Levine, 2004; Luintel et al., 2008). A visão baseada no setor bancário sustenta que os sistemas baseados em bancos, particularmente nos estágios iniciais de desenvolvimento econômico e em países com instituições fracas, produzem uma melhor alocação dos recursos disponíveis do que as instituições baseadas no mercado. Isto porque fazem melhor o trabalho em mobilizar poupanças e alocar capital, em diminuir as distorções emanadas da informação assimétrica, e em enfrentar problemas de agenciamento.

Em contraste, a visão baseada no mercado enfatiza que os mercados financeiros grandes, líquidos e que funcionam bem fornecem serviços financeiros que estimulam a inovação e crescimento de longo prazo, ao reforçar a governança corporativa e facilitar o gerenciamento de risco, através da diversificação e padronização das estruturas de gerenciamento de risco. Alternativamente, a visão de serviços financeiros minimiza o debate entre "bank based" e "market-based", destacando a qualidade dos serviços produzidos pelo sistema financeiro como um todo, e assinalando que os serviços financeiros em si mesmos são de longe mais importantes do que a forma se sua entrega; assim, a ênfase é na criação de bancos e mercados que funcionem bem ao invés do tipo de estrutura financeira. ${ }^{24}$

${ }^{21}$ Mesmo no caso do Japão, onde predominaram bancos privados, as linhas de financiamento de longo prazo eram subsidiadas pelo governo.

${ }^{22}$ Ver Hermann (2011) para uma análise da discussão teórica sobre o papel dos bancos públicos nos sistemas financeiros de países desenvolvidos e países em desenvolvimento.

23 A literatura mais recente tem utilizado o termo "bank-based financial system" e "market based financial system" (Levine, 2002).

${ }^{24}$ Neste sentido, The World Bank (2001, p.48) sustenta que "ambos o desenvolvimento de atividade bancária e das finanças de mercado pode ajudar o crescimento econômico: cada um complementa o outro". 
Luintel et al. (2008) reportam que vários estudos empíricos, utilizando dados em painel ou cross-section, encontram que o sistema baseado em bancos é superior ao baseado no mercado, e outros tantos sugerem o oposto; já alguns estudos, como Levine (2002), concluem que as evidências empíricas não provêm sustentação para as visões "bank-based" ou "market-based", de modo que a estrutura financeira não ajuda a explicar as diferenças de performance econômica de longo prazo. Demirguç-Kunt e Levine (2001), por sua vez, destacam que tal resultado não implica que a estrutura institucional não tem consequência para o crescimento, mas pode simplesmente indicar que não existe uma estrutura institucional ótima que seja adequada a todos e em qualquer tempo. Luintel et al. (2008), contudo, argumentam que as estimativas de painel podem ser enganosas considerando país, indústria e firma, não dando conta de forma suficiente da heterogeneidade entre os países, e podem assim mascarar diferenças entre eles na relação sob investigação, uma vez que países possuem diferentes estruturas produtivas, níveis diferenciados de desenvolvimento da atividade bancária e financeira e do mercado de capitais. Os autores, ao analisarem 14 países de média e baixa renda, usando métodos de séries temporais e painel heterogêneo dinâmico, encontram evidência de significativa heterogeneidade entre países na relação entre desenvolvimento financeiro, estrutura financeira e crescimento econômico, e que para a maioria dos países da amostra a estrutura financeira e desenvolvimento financeiro aparecem significativos para explicar níveis de produto.

As estruturas do sistema financeiro, sistemas financeiros segmentados ou sistemas financeiros baseados no banco universal, ou ainda "bank-based" ou "market-based", têm se alterado substancialmente em função das mudanças e desenvolvimentos recentes no sistema financeiro mundial, que têm resultado em boa medida do processo de desregulamentação financeira e dos desenvolvimentos tecnológicos em comunicações e informática. Em particular, o processo de desregulamentação financeira que ocorreu nos EUA nos anos 1980 e 1990 erodiu gradualmente as fronteiras que mantinham segmentados os distintos segmentos do sistema financeiro. Entre as tendências recentes do sistema financeiro, cabe destacar o desenvolvimento de instrumentos de securitização de dívidas, que resulta da acumulação de constrangimentos regulatórios sobre a atividade de empréstimo bancário, e que tem levado a um crescimento de formas de financiamento direto no mercado financeiro por parte de empresas e bancos; 
a emergência de investidores institucionais (seguradoras, fundos de pensão, fundos de investimento etc), que passam a ser um demandador importante de títulos de maturidade mais longa, tornando-se grandes ofertantes de recursos (e consequentemente serve de estímulo para securitização); desenvolvimento do mercado de derivativos, ${ }^{25}$ instrumentos que se desenvolveram principalmente a partir dos anos 1970 em função da maior volatilidade da taxa de juros e da taxa de câmbio, e que permitem decompor e negociar em separado os riscos que cercam uma dada transação financeira, mas que podem também servir como instrumento de especulação financeira; o declínio dos bancos comerciais e universalização dos bancos, ${ }^{26}$ que passam a diversificar suas atividades para além da atividade de intermediação financeira propriamente dita, incluindo atividades típicas de bancos de investimento, entre outras. ${ }^{27}$

Os efeitos sobre a disponibilidade e condições de financiamento das empresas são um pouco ambíguos. Por um lado, tais tendências contribuem para aumentar a oferta de financiamento quando comparado aos sistemas financeiros anteriores, em função das oportunidades criadas pela securitização, emergência de fundos de mercado monetário e diversificação da atuação dos bancos que passam também a atuar como promotores e garantidores da colocação dos títulos das empresas. Assim, em tese, as funções finance e funding do sistema financeiro deveriam ser beneficiadas por tais mudanças. Por outro lado, a desregulamentação financeira, tanto doméstica quanto internacional (fluxo de capitais entre países), aumenta o potencial de especulação por parte dos investidores e instituições financeiras que passam a se dar entre diferentes mercados domésticos e entre diferentes segmentos dos mercados financeiros dos países. Isto abre espaço para contágios, comportamento de manada, etc., o que pode resultar em maior volatilidade das variáveis macroeconômicas como taxa de juros e taxa de câmbio, sobretudo em países com sistemas financeiros pouco densos vis-à-vis ao volume de fluxos de capitais entre países. Assim, a dimensão minskiana da funcionalidade do sistema financeiro, ressaltada na seção anterior, de que sistemas financeiros bem desenvolvidos e bem regulamentados podem ajudar a

\footnotetext{
${ }^{25}$ A colocação de títulos, especialmente a dívida, por parte de empresas e governos beneficiouse da possibilidade de decompor seus riscos e formar seus preços de forma mais acurada.

${ }^{26}$ A reestruturação bancária que vem ocorrendo desde os anos 1980 tem acarretado nos países desenvolvidos uma diminuição da importância relativa dos depósitos à vista com fonte de recursos dos bancos, diminuição na margem líquida de juros e aumento nas receitas não financeiras dos bancos. Ver, a respeito, Paula (2011, cap. 7).

${ }^{27}$ Para um aprofundamento, ver Carvalho et al. (2007).
} 
atenuar a fragilidade financeira que é inerente a economias capitalistas em expansão, fica comprometida, como ficou evidente na recente crise financeira mundial.

De fato, a recente crise financeira internacional mostra o perigo de se confiar no funcionamento de um sistema financeiro desregulamentado. No mercado de títulos, como já assinalado, desenvolveram-se mecanismos de securitização, estimulados pelo crescimento de investidores institucionais, em que firmas e bancos se financiam "empacotando" rendas a receber. Uma vez que a securitização permitia a diluição de riscos no mercado, as instituições financeiras passaram a aumentar sua alavancagem, supondo que os mecanismos de auto-regulação do mercado seriam capazes de continuar avaliando corretamente os riscos inerentes às atividades financeiras. Em particular, os bancos há muito vinham utilizando de forma intensa inovações financeiras com o objetivo de alavancar suas operações sem ter de reservar os coeficientes de capital requeridos pelos acordos da Basiléia, em uma estratégia que só foi possível devido a existência de agentes que se dispuseram a assumir a contraparte dessas operações - um conjunto de instituições ficaram que ficaram depois conhecidas como "shadow banking system" ${ }^{28}$ (que incluía grandes bancos de investimentos independentes, hedge funds, fundos de pensão e seguradoras). Fica claro assim que a forte interação entre bancos universais e as demais instituições financeiras esteve por detrás dos instrumentos especulativos opacos que se desenvolveram até a crise financeira de 2007-08.

A crise do subprime - mercado de financiamento imobiliário de maior risco - acabou por expressar todas as contradições deste processo. A necessidade de ampliação de escala levou as instituições financeiras a incorporarem segmentos de baixa renda em condições de "exploração financeira" - no caso do subprime, com taxas de juros variáveis (baixas no início e se elevando ao longo do tempo) - que acabou resultando em um processo de estrangulamento financeiro do tomador de crédito. A securitização, que serviria para diluir riscos, na prática serviu para esconder riscos - títulos lastreados em hipotecas eram emitidos por instituições financeiras de grande porte, sendo tais ativos classificados como grau de investimento por uma agência de rating. Tais ativos, como resultado da globalização financeira, passaram, por sua vez, a ser comprados por investidores de diferentes

${ }^{28}$ Conforme Farhi et al. (2008). 
nacionalidades. Criaram-se, assim, novos instrumentos financeiros, que não foram devidamente regulamentados pelas autoridades monetárias. Mecanismos de autorregulação mostraram-se falhos devido ao caráter pró-cíclico da tomada de risco: projetos que eram considerados ruins na desaceleração passaram a ser visto como bons no boom cíclico. Como os mercados financeiros desregulamentados não são eficientes, na ausência de regras que estabilizem os referidos mercados, as atividades especulativas e a valorização financeira da riqueza afloram naturalmente. Isto porque a liberalização dos mercados financeiros e a existência de novos instrumentos financeiros (como derivativos) ampliaram a possibilidade de realização de atividades especulativas, dando origem a uma espécie de grande "cassino global" (Ferrari-Filho e Paula, 2010).

\section{Conclusão}

Este artigo mostrou que enquanto que na teoria convencional o sistema financeiro "funcional" é aquele que provê a melhor distribuição de informação para guiar consumidores e poupadores na alocação intertemporal da renda e riqueza, e que ao mesmo tempo permite reduzir os custos de transação na atividade de intermediação, na perspectiva pós-keynesiana um sistema financeiro macroeconomicamente funcional é aquele com poder de criação de crédito para atender a demanda de liquidez necessária para realização dos gastos pelos agentes, e ao mesmo tempo com capacidade de criar mecanismos financeiros apropriados para realização da consolidação das dívidas das firmas inversoras. Desse modo, ele pode permitir um ritmo de acumulação a um nível superior àquele que seria viável pela simples acumulação de poupanças prévias.

O papel do sistema financeiro, entretanto, é dúbio para o crescimento: ao mesmo tempo em que pode estimular um crescimento financeiramente estável, provendo liquidez e instrumentos adequados para realização do funding, ele pode ser instrumento de especulação, com efeitos deletérios para o crescimento do produto e do emprego. Isto porque, como salientou Minsky (1982, 1986), economias capitalistas em expansão se tornam crescentemente frágeis financeiramente devido à tendência inerente das estruturas financeiras capitalistas em se moverem de estado de robustez para um estado de 
fragilidade ao longo do tempo, que ocorre em função das mudanças nas expectativas dos agentes ao longo do ciclo econômico, e a forma como esta mudança é transmitida através do sistema financeiro, já que os bancos tendem a sancionar o declínio nas margens de segurança das firmas. Isto coloca a necessidade de se efetuar uma discussão aprofundada sobre critérios de regulação do sistema financeiro, que, ao mesmo tempo, em que iniba a especulação e operações financeiras opacas no sistema financeiro, não seja demasiado inibidor da expansão das atividades do setor bancário e do mercado de capitais.

A partir da perspectiva pós-keynesiana pode-se levantar algumas questões importantes relacionadas ao financiamento de economias em desenvolvimento. Em primeiro lugar, um sistema financeiro pode ser funcional do ponto de vista microeconômico (em termos operacionais e tecnológicos), mas não ser do ponto de vista macroeconômico, ou seja, no sentido de permitir um processo de expansão de uma economia financeiramente estável. ${ }^{29} \mathrm{Em}$ economias capitalistas em expansão, sobretudo economias em desenvolvimento, as instituições financeiras podem crescer sua lucratividade ofertando financiamento de curto prazo, sem que tenham, contudo, estímulo para financiar posições financeiras das firmas de mais longo prazo, em função da baixa sofisticação destes mercados e das elevadas incertezas que caracterizam tais economias (que frequentemente inibem relações financeiras de longo prazo em função de seus elevados riscos). Consequentemente, as firmas para expandirem suas atividades em uma economia em crescimento têm que recorrer à renovação de crédito de curto prazo, autofinanciamento e endividamento externo para implementar seus projetos de investimento, o que resulta um aumento da fragilidade financeira dessas unidades. Em segundo lugar, o conceito de funcionalidade do sistema financeiro supõe a existência de uma estrutura diversificada de instituições e instrumentos financeiros que possam oferecer alternativas de financiamento para os agentes realizarem seus gastos. Contudo, no caso dos países em desenvolvimento, caracterizados pela existência de sistemas financeiros ainda subdesenvolvidos e incompletos ${ }^{30}$ e por incertezas bem maiores do que nos países desenvolvidos (aumentando os riscos da

${ }^{29}$ Este foi o caso do sistema financeiro brasileiro, em particular nos anos 1980 e 1990, quando a relação crédito/PIB caiu dramaticamente, ao mesmo tempo em que o mercado de capitais pouco se desenvolveu.

${ }^{30}$ Mercados incompletos são definidos de forma ampla pela situação no qual segmentos do sistema financeiro (por exemplo, financiamento de longo prazo) não se desenvolvem por falta do desinteresse dos agentes seja do lado da demanda seja do lado da oferta deste sistema. 
atividade financeira), a questão de criação de condições apropriadas para coordenar e sustentar uma maior expansão econômica e uma distribuição de renda mais justa emerge naturalmente. Não há razão para supor que os mecanismos de financiamento e, sobretudo, de funding surjam espontaneamente pelo simples funcionamento do livre mercado. Isto pode abrir em muitas circunstâncias a necessidade de se ter um papel mais ativo do Estado como regulador e/ou financiador do desenvolvimento, de modo a propiciar uma alocação de recursos e riqueza mais eficiente na economia.

\section{Referências}

ALLEN, F. Presidential address: do financial institutions matter? Journal of Finance, v. 56, p. 1165$1175,2001$.

Allen, F \& SAntomero, A. M. The theory of financial intermediation. Journal of Banking and Finance, v.21, p. 1461-1485, 1997.

Allen, F \& SANTOMERo, A. M. What do financial intermediaries do? Wharton Financial Institutions Center, September 1999.

Alves JR., A.J., Ferrari Filho, F. \& PAUla, L.F. The post Keynesian critique of conventional currency crisis models and Davidson's proposal to reform the international monetary system. Journal of Post Keynesian Economics, v.22, n.2, p. 207-225, 2000.

Alves JR, A. J., Dymski, G. \& PAUla, L. F. Banking strategy and credit expansion: a post-Keynesian approach. Cambridge Journal of Economics, v. 32, p. 395-420, 2008.

BECK, T. \& LEVINE, R. Stock markets, banks and growth: panel evidence. Journal of Banking and Finance, v.28, p. 423-442, 2004.

BEnston, G.J. \& SMith Jr., C.W. A transactions cost approach to the theory of financial intermediation. Journal of Finance, v. 31, p. 215-231, 1976.

CAMPBELL, T. S., \& KRACAW, W.A. Information production, market signaling, and the theory of financial intermediation. Journal of Finance, v.35, p. 863-882, 1980.

Cavalcante, A., Crocco, M. \& Jayme JR, F. G. Preferência pela liquidez, sistema bancário e disponibilidade de crédito regional. Textos para Discussão Cedeplar-UFMG 237, 2004.

Carvalho, F.C. Mr. Keynes and the Post keynesians. Cheltenham: Edward Elgar, 1992.

CARVALHO, F.C. Sorting the issues out: the two debates (1936/7; 1983/6) on Keynes's finance revisited. Revista Brasileira de Economia v. 50, n.3, p. 312-327, 1996.

CARvalho, F.C. Financial Innovation and the Post Keynesian Approach to the Process of Capital Formation . Journal of Post Keynesian Economics, v. 19, n.3, p. 461-487, 1997.

Carvalho, F. C. \& Kregel, J. Crise Financeira e Déficit Democrático. Rio de Janeiro: IBASE, 2008.

CARvalho, F. C., Souza, F.E.P., Sicsú, J., PAula, L.F.\& Studart, R. Economia Monetária e Financeira: Teoria e Política. $2^{\mathrm{a}}$ edição. Rio de Janeiro: Campus/Elsevier, 2007.

CHICK, V. The evolution of the banking system and the theory of saving, investment and interest. In. CHICK, V. On Money, Method and Keynes: Selected Essays. London: MacMillan, 1992

DAVIDSON, P. Money and the Real World. London: MacMillan, 1972.

Est. Econ., São Paulo, vol. 43, n.2, p. 363-396, abr.-jun. 2013 
DAVIDSON, P. Finance, funding, saving, and investment. Journal of Post Keynesian Economics, v. 9, n. 1, p. 101-110, 1986.

DEMIRGUÇ-Kunt \& LEVINE, R. Financial Structures and Economic Growth: A Cross-Country Comparison of Banks, Markets and Development. Cambridge, MA: MIT Press, 2001.

DiAmond, D. Financial intermediation and delegated monitoring. Review of Economic Studies, v. LI, p. 393-414, 1984.

DiAmOND, D.W., \& RAJAN, R.G. A theory of bank capital. Journal of Finance, v. 55, p. 2431-2465, 2000.

Dow, S. C. Money and the Economic Process. Aldershot, Edward Elgar, 1993

Farhi, M., Prates, D.M., Freitas, M.C.P. \& CinTra, M.A.M. A crise e os desafios para a nova arquitetura financeira internacional. In Associação Keynesiana Brasileira, Dossiê da Crise. Porto Alegre: AKB, 2008.

FAMA, E.F. Banking and theory of finance. Journal of Monetary Economics, v.10, p.39-57, 1980.

FERRARI-FILHO, F. \& PAULA, L.F. Crise financeira e reestruturação do sistema monetário internacional'. Indicadores FEE, v. 37, n. 1, p. 113-117, 2010.

Gerschenkron, A. Economic Backwardness in Historical Perspective: A Book of Essays. London: The Belknap Press of Harvard University Press, 1962.

Gorton, G. \& Winton, A. A financial intermediation . In CONSTANTINIDEs, G., HARRis, M. \& StUlz, R. (ed.). Handbook of the Economics of Finance, vol.1A. London: Elsevier, 2003.

GURLEY, J. \& SHAW, E. Financial aspects of economic development. American Economic Review, v. XLV, n. 4, p. 515-538, 1955.

GurLey, J. \& SHAW, E. Money in a Theory of Finance. Washington, D. C.: The Brookings Institution, 1960.

GutTentag, J.M., \& Lindsay, R. The uniqueness of commercial banks. Journal of Political Economy, v. 71, p. 991-1014, 1968.

HERMAnN, J. Bancos públicos em sistemas financeiros maduros: perspectivas teóricas e desafios para os países em desenvolvimento. Revista de Economia Política, v. 31, n. 3, p.394-414, 2011.

HeRmanN, J. \& PAUla, L.F. Economic development and the functionality of the financial system in Brazil: a Keynesian approach. Paper apresentado no $8^{\text {th }}$ International Conference Developments, Bilbao/Espanha, 29/6/2011.

KeYNES, J. M. Treatise on Money, Collected Writtings V and VI. London: MacMillan, 1930/1971.

KEYNES, J. M. The General Theory of Employment, Interest and Money. London: Palgrave MacMillan, 1936/2007.

KEYNES, J. M. The ex-ante theory of the rate of interest. Economic Journal, v.47, p.663-669,1937.

KEYNES, J. M. The process of capital formation. Economic Journal, v.49, n.195, p.558-577,1939.

KREGEL, J. A note on finance, liquidity, saving, and investment . Journal of Post Keynesian Economics, v. 9, n. 1, p. 91-100, 1986.

LELAND, H.E. \& PYLE, D.H. Informational asymmetries, financial structure, and financial intermediation. Journal of Finance, v. 32, p.371-387, 1977.

LEVINE, R. Financial development and economic growth: views and agenda. Journal of Economic Literature, XXXV, p. 688-726, 1997.

LEVINE, R. Bank-based or market-based financial systems: Which is better? NBER Working Paper No. 9138, September 2002.

Luintel, K.B., KHAN, M., ARESTIS, A. \& P. ThEODORIDIS, K. Financial structure and economic growth. Journal of Development Economics, v.86, p. 181-200, 2008.

MCKInNON, R. Money and Capital in Economic Development. Washington: Brookings Institution, 1973.

MANKIw, N.G. The allocation of credit and financial collapse. Quarterly Journal of Economics, v. 101, p. $455-470,1986$ 
Matheus, K. \& Thompson, J. The Economics of Banking. Chichester: Wiley, 2008.

Menezes, M., Crocco M., SANCheS, E. \& AMADO, A. Sistema financeiro e desenvolvimento regional: notas exploratórias. In PAULA, L.F. \& OREIRo, J.L. Sistema Financeiro: Uma Análise do Setor Bancário Brasileiro. Rio de Janeiro: Elsevier-Campus, 2007.

MERTON, R.C. Operation and regulation in financial intermediation: a functional perspective. In ENLGUND, P. (ed), Operation and Regulation of Financial Markets. Stockolm: Economic Council, 1993.

MERTON, R.C. Financial innovation and the management and regulation of financial institutions. Journal of Banking and Finance, v. 19, p. 461-481, 1995.

Minsky, P. H. John Maynard Keynes. New York: Columbia University Press, 1975.

Minsky, P. H. Can 'It' Happen Again? Essays on Instability and Finance. Armonk. New York: M.E. Sharpe, 1982.

MODENESI, A.M. Teoria da intermediação financeira, o modelo ECD e sua aplicação aos bancos: uma resenha . In PAULA, L.F. \& OREIRO, J.L. (org). Sistema Financeiro: uma análise do setor bancário brasileiro. Rio de Janeiro: Campus/Elsevier, 2007.

PAULA, L.F. Financial Liberalization and Economic Performance: Brazil at the Crossroads. London: Routledge, 2011.

PAULA, L. F.\& ALVES JR, A.J. External financial fragility and the 1998-1999 Brazilian currency crisis. Journal of Post Keynesian Economics, v. 24, n.4, p. 589-617, 2000.

PATRICK, H.T. Financial development and economic growth in underdeveloped countries. Economic Development and Cultural Change, v.14, n.2, p.174-198, 1966.

RESENDE, M.F.C. O circuito finance-investimento-poupança-funding em economias abertas. Revista de Economia Política, v. 28, n. 1, p. 136-154, 2007.

SCHoltens, B. e WensveEn, D. A critique on the theory of financial intermediation. Journal of Banking and Finance, v. 24, p. 1243-1251, 2000.

SCHOLTENS, B. \& WensVEen, D. The theory of financial intermediation: an essay on what it does (not) explain. SUERF Studies, 2003/1, 2003.

SChumpeter, J. A. The Theory of Economic Development. Piscataway, New Jersey: Transaction Publishers, 1911/1982.

SHaw, E. S. Financial Deepening in Economic Development. New York: Oxford University, 1973.

Stiglitz, J. The role of the state in financial markets. Proceedings of the World Bank Annual Conference on Development Economics 1993, 1994.

StiglitZ, J. The role of the financial system in development. The World Bank Group, Presentation at the Fourth Annual Bank Conference on development in Latin America and the Caribbean (LACABCDE). The World Bank, 1998.

StiglitZ, J. e WeISS, A. A credit rationing in markets with imperfect information. American Economic Review v. 71, n. 3, p. 393-410, 1998.

STUDART, R. The efficiency of financial systems, liberalization, and economic development. Journal of Post Keynesian Economics, v. 18, n. 2, p. 269-292, 1995-96.

STUDART, R. O sistema financeiro e o financiamento do crescimento: uma alternativa pós-keynesiana a visão convencional . In LiMA, G.L., Sicsú, J. \& PAULA, L. F. (org.). Macroeconomia Moderna. Rio de Janeiro: Campus, 1999.

TORRES FilHo. E.T. \& MACAHYBA, L. O Elo Perdido: O Mercado de Títulos de Dívida Corporativa no Brasil: Avaliação e Propostas. São Paulo: IEDI/Instituto Talento Brasil, 2002.

WORLD BANK. Finance for growth: policy choices in a volatile world. A World Bank Policy Research Report. Washington: World Bank, 2001.

ZYSMAN, J. Governments, Markets and Growth. London: Cornell University Press, 1983. 